\title{
Hepatitis B and C viral infections among blood donors. A retrospective study from a rural community of Ghana
}

\author{
Bernard Nkrumah" ${ }^{*}$, Michael Owusu² and Paul Averu $^{3}$
}

\begin{abstract}
Background: Infection by Hepatitis B virus (HBV) and Hepatitis C virus (HCV) cause serious mortality, morbidity and financial burden and are thus a major global health problem. The study was conducted to investigate the prevalence of Hepatitis B and C infections and co-infections among blood donors in a rural community of Ghana. This was a retrospective study conducted at the Agogo Presbyterian Hospital in the Asanti Akim North District of Ghana to investigate the prevalence of these infections over a three year period among 2773 blood donors. Males constituted a larger proportion of the study population (92.2\%). Majority of the study population (43.9\%) were within 26-35 age group. The disease prevalence was calculated at a 95\% confidence interval.

Findings: The prevalence of Hepatitis B viral (HBV) infection was highest in females- $21.4 \%$ (95\% Cl: 11.6-34.4) in 2006 than males in the same year- 13.2\% (95\% Cl: 10.8-15.9). Hepatitis C viral (HCV) infection was highest among males- 11.6\% (95\% Cl: 9.5-13.8) in 2007. HBV and HCV co-infection was higher in males- $2.6 \%$ (95\% Cl: 1.6-3.8) than females- 1.3\% (95\% Cl: 0-7.0) in 2007. The overall prevalence of HBV and HCV was 13.8\% (95\% Cl: 11.4- 16.4) and 9.4\% (95\% Cl: 7.4-11.6) respectively in 2006. The rate of co-infection of HBV and HCV however increased from 1.6\% ( $95 \%$ Cl: $0.8-2.7)$ in 2006 to $2.2 \%$ (95\% Cl: 1.3-3.2) in 2008 in males and from $0 \%$ (95\% Cl: 0-6.4) in 2006 to $1.2 \%$ (95\% Cl: 0-6.5) in 2008 in females.

Conclusion: The single infections of HBV and HCV reduced but co-infection of these transfusion transmitted infections increased. Measures such as more sensitive techniques for effective diagnosis and sanitary education to enlighten the population must be implemented.
\end{abstract}

\section{Introduction}

Hepatitis B is one of most common infectious diseases of the world infecting two billion people including an estimated 400 million chronically infected cases [1]. Individuals with chronic infection have a high risk of developing liver cirrhosis and hepatocellular carcinoma. Hepatitis $C$ virus infection is another common chronic blood borne infection with an estimated 3.9 million persons infected with the virus and have a high rate of development of liver cirrhosis. Infection by Hepatitis B virus (HBV) and Hepatitis $\mathrm{C}$ virus (HCV) cause serious mortality, morbidity and financial burden and are thus a major global health problem [2]. Few studies have

\footnotetext{
* Correspondence: skrakyo@yahoo.com

'Kumasi Centre for Collaborative Research in Tropical Medicine, Kumasi, Ghana

Full list of author information is available at the end of the article
}

previously indicated the high prevalence of HBV in Ghana $[3,4]$ and predonation screening of blood donors or screening of donated blood for $\mathrm{HBV}$ and $\mathrm{HCV}$ are thus a routine practice. $\mathrm{HCV}$ is recognized as the primary cause of transfusion-associated non-A-non-B viral hepatitis worldwide [5] and is endemic in West Africa [6]. In 1996, Martinson and his group conducted a seroepidemiological survey of Hepatitis $B$ and $C$ virus infections in children attending school in Ashanti-Akim North district and showed that the overall HBV and HCV seroprevalence was $15.8 \%$ and $5.4 \%$ respectively [4] but recent studies conducted among blood donors in Ethiopia has shown decreasing trends of HBV and $\mathrm{HCV}$ [7]. From the Biostatistics department of the hospital, the prevalence of HBV and HCV in 2007 stood at 15.1\% and $7.9 \%$ respectively (unpublished data).

\section{Biomed Central}


Information on $\mathrm{HBV}$ and $\mathrm{HCV}$ seroprevalence in Ghana are old, scanty or limited to only urban blood donors. The study aim was therefore to determine the prevalence of $\mathrm{HBV}$ and $\mathrm{HCV}$ in blood donors in a rural area over a three year period (2006-2008).

\section{Methods}

\section{Study site}

The Agogo Presbyterian Hospital is located in the Asanti Akim North District of the Ashanti Region of Ghana, West Africa; and is the principal hospital of the district. The District is located in the eastern part of Ashanti Region and covers a land area of $1,160 \mathrm{~km}^{2}$ with an estimated population of 142,434 (projection from 2000 Population Census). The catchment population of the hospital encompasses around 70,000 people, about 25,000 in Agogo itself. Agogo is surrounded by hills covered with tropical secondary forests, subsistence and small commercial acreages, grass and bush land that had emerged after forest clearing due to logging and farming activities. The most important cash crops are cocoa and oil palm. Bananas, plantains, yams, cassava and maize are the most important crops for subsistence farming.

\section{Study population}

This consisted of voluntary and replacement donors who presented to the blood bank of the hospital. Between January 2006 and December 2008, serological screening results from 2773 blood donors were obtained from the hospital's archive. Prospective donors between the ages of 17-60 years who pass a history screen of their medical and physical state and predonation screening test for $\mathrm{Hb}$ level, HBV, HCV, Syphilis and HIV were considered fit to donate blood.

\section{Sampling}

The screening of blood donors or donated blood for HBsAg and anti-HCV is mandatory thus blood donations from individuals who are found to be positive for any of the above infections were not done. Archived results from the hospitals blood bank was used for this study with approval from the hospital authorities. The donor samples were tested using the DiaSpot ${ }^{\circledR}$ One Step Hepatitis test kits (DiaSpot Rapid Diagnosis, Pondok Kelapa 13450, Jakarta Indonesia). The tests were carried out according to the manufacturer's instructions.

\section{Quality control}

In house positive and negative controls were performed for each reagent lot.

\section{Statistical analysis}

Data were double-entered into a predesigned electronic database using Epi info version 6.04dfr (Center for
Disease Control, Atlanta, GA, USA) and cleaned. Data was exported to Stata/SE11.1 statistical software (Stata Corporation, Texas USA) for analysis. The prevalence was calculated at a $95 \%$ confidence interval.

\section{Ethical Approval}

Ethical approval for the study was obtained from the Committee on Human Research, Publication and Ethics (CHRPE), of the School of Medical Sciences, KNUSTKumasi.

\section{Results}

A total of 2773 prospective blood donors were screened from January 2006 to December 2008. Study participants were grouped into five age categories (Table 1). Out of these, 2556 (92.2\%) were males and 217 (7.8\%) were females. Donors were categorized into five age groups. The majority of the study population- 1217 (43.9\%) - were within the 26-35 age group. Analysis of the prevalence of $\mathrm{HBV}$ and $\mathrm{HCV}$ among males and females revealed a statistically significant decrease in the occurrence of the infections among males and females (Table 2). Of the total number, 10.53\% (292/2773), $5.63 \%(156 / 2773)$ and $2.09 \%(58 / 2773)$ were HBV, HCV and both $\mathrm{HBV}$ and $\mathrm{HCV}$ positive, respectively. Furthermore, the prevalence of co-infection of HBV and HCV decreased for the years under review with the highest rate peaking at 2.6\% (95\% CI: 1.6-3.6) in 2007 (Figure 1 ). The overall prevalence rate for $\mathrm{HBV}$ was highest in 2006 (13.8\%; 95\% CI: 11.4-16.4) but decreased in 2008 to $6.9 \%$ (95\% CI: 5.4-8.6) (Figure 2). The overall prevalence of HCV was highest in 2007 (11.1\%; 95\% CI: 9.213.2) but decreased to $7.0 \%$ (95\% CI: 5.5-8.8) in 2008. The prevalence rate of $\mathrm{HBV}$ was relatively higher in females but vice versa for HCV (Figure 3).

\section{Discussion}

$\mathrm{HBV}$ and HCV infections occurrence among blood donors in a rural setting was determined by serological methods and the results were compared to assess the trends in three consecutive years, 2006, 2007 and 2008. The prevalence of viral carrier rates in the blood donors appears to be different to that of urban blood donors as shown in the data with a decrease in HBV and HCV.

Table 1 Age categories of the study population

\begin{tabular}{cccccccc}
\hline & \multicolumn{2}{c}{2006} & \multicolumn{2}{c}{$\mathbf{2 0 0 7}$} & \multicolumn{2}{c}{$\mathbf{2 0 0 8}$} & \multirow{2}{*}{ Total } \\
\cline { 1 - 6 } Age Group & Male & Female & Male & Female & Male & Female & \\
\cline { 1 - 7 } $16-25$ & 194 & 25 & 198 & 37 & 254 & 49 & 757 \\
$26-35$ & 297 & 15 & 450 & 21 & 413 & 21 & 1217 \\
$36-45$ & 152 & 5 & 183 & 13 & 203 & 9 & 565 \\
$46-55$ & 64 & 5 & 61 & 4 & 61 & 5 & 200 \\
$56-65$ & 7 & 6 & 8 & 2 & 11 & 0 & 34 \\
\hline
\end{tabular}


Table 2 Co-infection of HBV/HCV from 2006 to 2008

\begin{tabular}{|c|c|c|c|c|c|c|c|c|c|}
\hline \multirow[b]{3}{*}{ Year } & \multicolumn{9}{|c|}{ Prevalence at $95 \% \mathrm{Cl}$} \\
\hline & \multicolumn{2}{|c|}{ HBV only } & \multicolumn{2}{|c|}{ HCV only } & \multicolumn{2}{|c|}{ Both HBV and HCV } & \multicolumn{3}{|c|}{ Overall Prevalence } \\
\hline & Male & Female & Male & Female & Male & Female & HBV & $\mathrm{HCV}$ & Both HBV and HCV \\
\hline \multirow[t]{2}{*}{2006} & $13.2^{\dagger}$ & 21.4 & 10.1 & 0 & 1.6 & 0 & 13.8 & 9.4 & 1.6 \\
\hline & $(10.8-15.9)^{*}$ & $(11.6-34.4)$ & $(8.0-12.5)$ & $(0-6.4)$ & $(0.9-2.9)$ & $(0-6.4)$ & $(11.4-16.4)$ & $(7.4-11.6)$ & $(0.8-2.7)$ \\
\hline \multirow[t]{2}{*}{2007} & 11.3 & 16.9 & 11.6 & 5.2 & 2.6 & 1.3 & 11.8 & 11.1 & 2.6 \\
\hline & $(9.3-13.6)$ & $(9.3-27.1)$ & $(9.5-13.8)$ & $(1.4-12.8)$ & $(1.6-3.8)$ & $(0-7.0)$ & $(9.8-14.0)$ & $(9.2-13.2)$ & $(1.6-3.6)$ \\
\hline \multirow[t]{2}{*}{2008} & 6.7 & 9.5 & 7.3 & 3.6 & 2.2 & 1.2 & 6.9 & 7 & 2.2 \\
\hline & $(5.2-8.5)$ & $(4.2-17.9)$ & $(5.7-9.2)$ & $(0.7-10.1)$ & $(1.4-3.4)$ & $(0-6.5)$ & $(5.4-8.6)$ & $(5.5-8.8)$ & $(1.3-3.2)$ \\
\hline
\end{tabular}

† Percentage prevalence

* Confidence interval

Statistics from earlier studies showed high rates of HBV and $\mathrm{HCV}$ in urban blood donors [7-9]. Simultaneous increase of HBV and HCV infections might have been caused by sexual transmission through unprotected sex and other practices [10-12]. Our study raises serious concerns regarding the safety of the blood supply in our rural communities where resources are hard to come by. The decreasing rate of positivity to $\mathrm{HBV}$ and $\mathrm{HCV}$ or both suggests that horizontal rather than vertical transmission is the major source of this endemicity [10]. In areas of low endemicity, transmission occurs primarily among young adults [13] and there is an age effect on the prevalence of HBV and HCV infections [14]. Horizontal transmission of HBV and HCV have been related to age, socioeconomic conditions, socio professional status and risky behaviors such as sharing of bath towels, chewing gum, partially eaten candies, or dental cleaning materials, as well as biting fingernails in conjunction with scratching the backs of carriers [15-17]. It has been shown that the improvement of socioeconomic conditions may lead to a decreasing exposure to HBV and $\mathrm{HCV}$ infections [17] thus an increased risk of HBV and $\mathrm{HCV}$ infections might be related to an increased

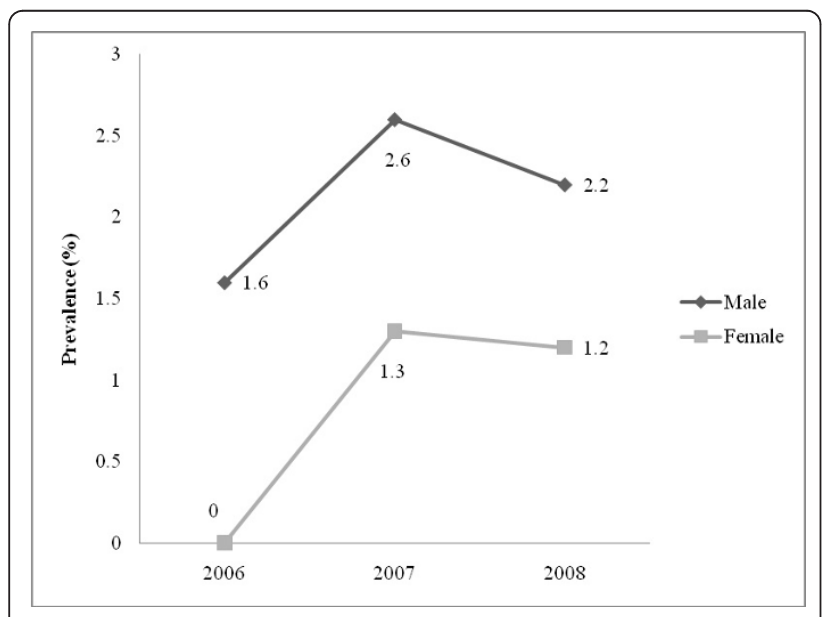

Figure $1 \mathrm{HBV}$ and $\mathrm{HCV}$ co-infection among males and females. exposure to risk factors in conjunction with poor sanitary and socioeconomic conditions. The decreasing trend of HBV and HCV infections in our study population might be due to decreased exposure to risk factors in conjunction with improving sanitary and socioeconomic conditions. The fact that our study community is being educated through weekly radio health talk programmes on these diseases in terms of good life style practices such as having protected sex, not sharing razors and needles with other people among others are been adhered to. Another possible reason might be the fact that screening of blood donors for HBsAg and anti$\mathrm{HCV}$ does not totally eliminate the risk of HBV and $\mathrm{HCV}$ infection through blood transfusion since donors with occult $\mathrm{HBV}$ and $\mathrm{HCV}$ infection which lacked detectable levels of HBsAg and anti-HCV [18] were screened as negative. This emphasizes the need for a more sensitive and stringent screening algorithm for blood donations even in rural settings.

\section{Conclusion}

HBV and/or HCV infection(s) among blood donors in the study area is/are reducing. The occurrence of these

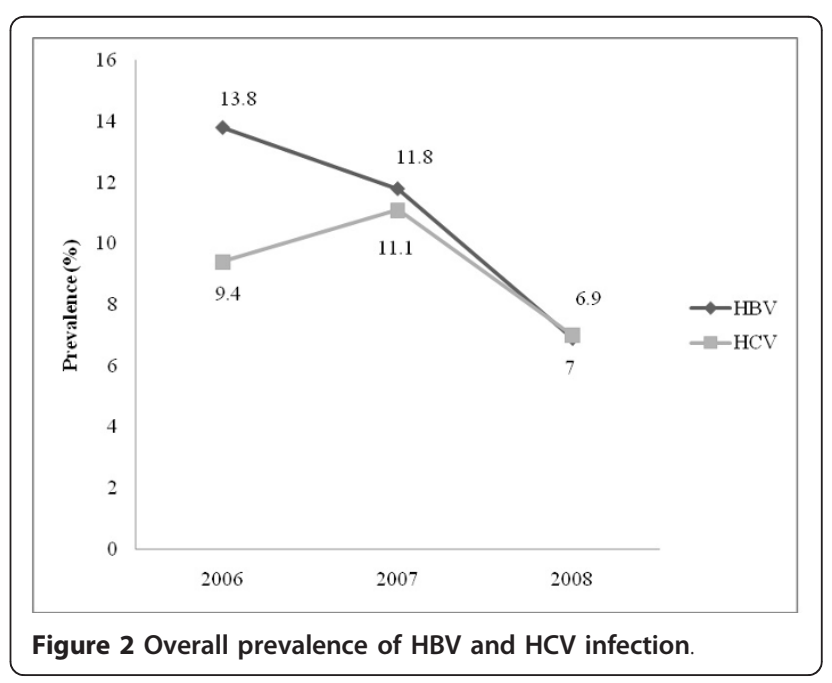




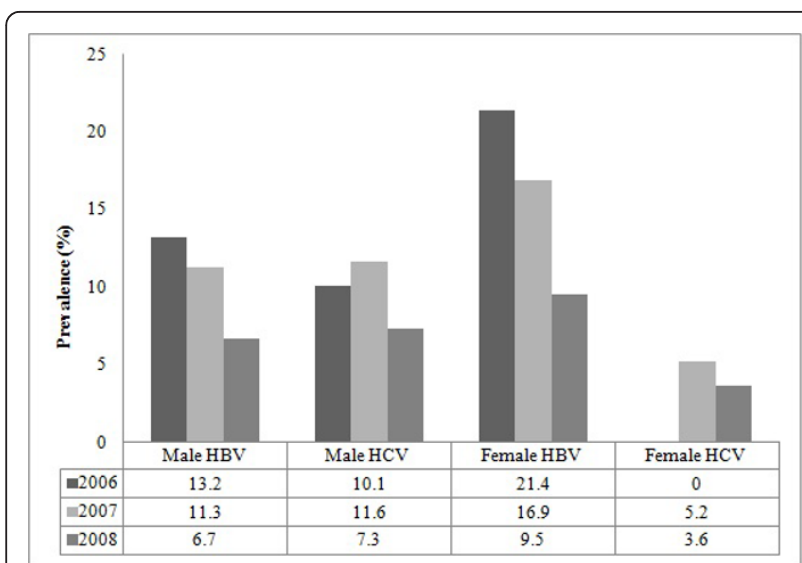

Figure 3 Prevalence of HBV and HCV infection among males and females.

infections among the blood donors should still be monitored carefully to further reduce the rates to ensure safer and more reliable blood for transfusion. Measures such as more sensitive techniques, education, sensitization and vaccination must be carried out to ensure that people are well enlightened and protected from these infections.

\section{Acknowledgements}

We wish to thank the hospital authorities for giving us the permission to use data from their Archived results for this study. We sincerely thank the staff of the Agogo Presbyterian Hospital Laboratory Agogo, Asanti Akim North-Ghana for their co-operation and interest in this study.

Disclaimer

The findings and conclusions in this paper are those of the authors and do not necessarily represent the views of any of their affiliated Research Institutions.

\section{Author details}

'Kumasi Centre for Collaborative Research in Tropical Medicine, Kumasi, Ghana. ${ }^{2}$ Komfo Anokye Teaching Hospital, Kumasi, Ghana. ${ }^{3}$ Agogo

Presbyterian Hospital, Asanti Akim North, Asanti Region, Ghana.

\section{Authors' contributions}

BN designed the study protocol, analyzed and interpreted the data and headed the writing of the protocol. $\mathrm{MO}$ contributed to the writing of the manuscript. PA headed the laboratory team and contributed to the writing of the manuscript. All authors have read and approved the final version of this manuscript.

\section{Competing interests}

The authors declare that they have no competing interests.

Received: 30 June 2011 Accepted: 12 December 2011 Published: 12 December 2011

\section{References}

1. Schreiber GB, Busch MP, Kleinman SH, Korelitz JJ: The risk of transfusion transmitted viral infections. The New England Journal of Medicine 1996, 334(26):1685-1690.

2. Kleinman SH, Kuhns MC, Todd DS, Glynn SA, McNamara A, DiMarco A Frequency of HBV DNA detection in US blood donors testing positive for the presence of anti $\mathrm{HBc}$ : implications for transfusion transmission and donor screening. Transfusion 2003, 43(6):696-704.
3. Acquaye JK, Mingle JA: Hepatitis B viral markers in Ghanaian pregnant women. West African Journal of Medicine 1994, 13(3):134.

4. Martinson FEA, Weigle KA, Mushahwar IK, Weber DJ, Royce R, Lemon SM: Seroepidemiological survey of hepatitis $B$ and $C$ virus infections in Ghanaian children. Journal of Medical Virology 1996, 48(3):278-283.

5. Houghton M, Weiner A, Han J, Kuo G, Choo QL: Molecular biology of the hepatitis $C$ viruses: implications for diagnosis, development and control of viral disease. Hepatology 1991, 14(2):381-388.

6. Jeannel D, Fretz C, Traore Y, Kohdjo N, Bigot A, Gamy EP, Jourdan G, Kourouma K, Maertens G, Fumoux F: Evidence for high genetic diversity and long term endemicity of hepatitis $C$ virus genotypes 1 and 2 in West Africa. Journal of Medical Virology 1998, 55(2):92-97.

7. Tessema B, Yismaw G, Kassu A, Amsalu A, Mulu A, Emmrich F, Sack U: Seroprevalence of HIV, HBV, HCV and syphilis infections among blood donors at Gondar University Teaching Hospital, Northwest Ethiopia: declining trends over a period of five years. BMC Infectious Diseases 10(1):111.

8. Ampofo W, Nii-Trebi N, Ansah J, Abe K, Naito H, Aidoo S, Nuvor V, Brandful J, Yamamoto N, Ofori-Adjei D: Prevalence of blood-borne infectious diseases in blood donors in Ghana. Journal of Clinical Microbiology 2002, 40(9):3523.

9. Allain JP, Candotti D, Soldan K, Sarkodie F, Phelps B, Giachetti C, Shyamala V, Yeboah F, Anokwa M, Owusu-Ofori S: The risk of hepatitis B virus infection by transfusion in Kumasi, Ghana. Blood 2003, 101(6):2419.

10. Cisneros-Castolo M, Hernandez-Ruiz L, Ibarra-Robles IE, FernandezGarate RH, Escobedo-De La Pena J: Prevalence of hepatitis B virus infection and related risk factors in a rural community of Mexico. The American Journal of Tropical Medicine and Hygiene 2001, 65(6):759.

11. Rouet F, Chaix ML, Inwoley A, Msellati P, Viho I, Combe P, Leroy V, Dabis F, Rouzioux C: HBV and HCV prevalence and viraemia in HIV positive and HIV negative pregnant women in Abidjan, Côte d'Ivoire: The ANRS 1236 study. Journal of Medical Virology 2004, 74(1):34-40.

12. Ghebrekidan H, Cox S, Wahren B, Grandien M: Prevalence of infection with HIV, hepatitis B and C viruses, in four high risk groups in Eritrea. Clinical and Diagnostic Virology 1998, 9(1):29-35.

13. Shapiro CN, Margolis HS: Hepatitis B epidemiology and prevention. Epidemiologic Reviews 1990, 12(1):221.

14. Coleman PJ, McQuillan GM, Moyer LA, Lambert SB, Margolis HS: Incidence of hepatitis B virus infection in the United States, 1976-1994: estimates from the National Health and Nutrition Examination Surveys. Journal of Infectious Diseases 1998, 178(4):954.

15. Viel JF, Fest T, Dussaucy A, Pobel D, Agis F: Hepatitis B virus infection on a tropical island: sociodemographic and geographic risk factors in Guadeloupe. The American Journal of Tropical Medicine and Hygiene 1995, 52(5):398.

16. Furusyo N, Hayashi J, Sawayama Y, Kawakami Y, Kishihara Y, Kashiwagi S: The elimination of hepatitis $B$ virus infection: changing seroepidemiology of hepatitis A and B virus infection in Okinawa, Japan over a 26-year period. The American Journal of Tropical Medicine and Hygiene 1998, 59(5):693.

17. Martinson FEA, Weigle KA, Royce RA, Weber DJ, Suchindran CM, Lemon SM: Risk factors for horizontal transmission of hepatitis $B$ virus in a rural district in Ghana. American Journal of Epidemiology 1998, 147(5):478.

18. Allain JP: Occult hepatitis B virus infection. Transfusion clinique et biologique 2004, 11(1):18-25.

doi:10.1186/1756-0500-4-529

Cite this article as: Nkrumah et al:: Hepatitis B and $C$ viral infections among blood donors. A retrospective study from a rural community of Ghana. BMC Research Notes 2011 4:529. 